\title{
Uudet typpilannoituskokeet haastavat vanhat käsitykset nurmien satovasteista
}

\author{
Perttu Virkajärvi ${ }^{1}$, Sanna Kykkänen ${ }^{1}$, Maarit Hyrkäs ${ }^{1}$, Panu Korhonen ${ }^{1}$, Miika Hartikainen ${ }^{2}$, Anna \\ Kärkönen ${ }^{3}$, Minna Toivakka ${ }^{4}$ ja Raimo Kauppila ${ }^{4}$ \\ ${ }^{1}$ Luonnonvarakeskus, Tuotantojärjestelmät, Halolantie 31 A, 71750 Maaninka \\ ${ }^{2}$ Luonnonvarakeskus, Tuotantojärjestelmät, Tutkimusasemantie 15, 92400 Ruukki \\ ${ }^{3}$ Luonnonvarakeskus, Tuotantojärjestelmät, Latokartanonkaari 9, 00790 Helsinki \\ ${ }^{4}$ Yara Suomi Oy, Bertel Jungin aukio 9, 02600 Espoo \\ etunimi.sukunimi@luke.fi
}

Typpilannoituksen satovastefunktio on merkittävä sekä nurmen sadontuoton että viljelyn ympäristökuormituksen kannalta. Uusimmissa yhteenvedoissa käytetyt satovastefunktiot perustuvat pääosin 1960-1970 luvulta peräisin oleviin aineistoihin. Viimeaikaiset havainnot nurmen korkeista sadoista sekä kokeissa että maatiloilla antavat aiheen epäillä olemassa olevien satofunktioiden ajantasaisuutta. Luonnonvarakeskuksen (Luke) ja Yaran yhteistyötutkimuksen tavoitteena oli selvittää typpilannoituksen vaikutus uusien nurmikasvilajikkeiden kasvuun, rehuarvoon ja ravinnetaseisiin. Tutkimus toteutettiin Luken toimipaikoissa Maaningalla ja Ruukissa. Kokeet perustettiin kivennäismaille (Maaninka: karkea hieta, orgaaninen aines 2.7\%; Ruukki: hieno hieta, orgaaninen aines 5.4\%) vuonna 2014 ja käsittelyt toteutettiin vuosina 2015-2017. Kokeessa oli neljä toistoa ja koeruudut niitettiin kolmesti vuodessa. Pär̈ruutuina olivat timoteilajikkeet Nuutti ja Grindstad sekä nurminata Valtteri. Osaruutuina olivat 8 typpilannoitustasoa (0, 150, 200, 250, 300, 350, 400, $450 \mathrm{~kg} \mathrm{~N} \mathrm{ha}^{-1} \mathrm{v}^{-1}$ ), joista kahden korkeimman tason oletettiin alentavan satoa mahdollisten lisääntyvien talvituhojen takia. Typpilannoitus jaettiin niittojen välillä (1., 2. ja 3. niitto) suhteessa $0.44-0.36-0.20$. Sekä vanhoissa aineistoissa että uudessa aineistossa typen satofunktio oli muodoltaan toisen asteen polynomi. Uudessa koesarjassa satovaste oli selvästi parempi kuin vanhoissa koeaineistoissa: vanhassa satofunktiossa satomaksimi oli 8.5 tn kuiva-ainetta $(\mathrm{ka}) \mathrm{ha}^{-1} \mathrm{v}^{-1}$, mikä saatiin $325 \quad \mathrm{~kg} \quad \mathrm{~N} \quad \mathrm{ha}^{-1}$ $\mathrm{v}^{-1}$ lannoituksella. Kolmen koevuoden perusteella (molemmat koepaikat, kaikki lajikkeet) samalla lannoituksella nurmi tuotti 12.4 tn $\mathrm{ka} \mathrm{ha}^{-1} \mathrm{v}^{-1}$ eli $43 \%$ enemmän kuin vanhassa aineistossa. Funktion mukainen satomaksimi oli aiempaa korkeampi eli 14 tn $\mathrm{ka} \mathrm{ha}^{-1} \mathrm{v}^{-1}$, joka saavutettiin $420 \mathrm{~kg} \mathrm{~N} \mathrm{ha-1}$ vuosilannoituksella. Taloudellinen optimi on tätä matalampi. Kolmantena vuonna (2017) satotaso oli hieman alhaisempi ja typen vaste hieman matalampi kuin kokeen kahtena ensimmäisenä vuonna. Nurmen raakavalkuaispitoisuus nousi typpilannoituksen kasvaessa uudessa aineistossa hitaammin kuin aikaisemmissa kokeissa. Silti korkean sadontuoton seurauksena typen hyväksikäyttö oli parempi kuin aiemmissa kokeissa ja siksi typpitase saavutti suositellun maksimirajan $+60 \mathrm{~kg} \mathrm{~N} \mathrm{ha}^{-1} \mathrm{v}^{-1}$ vasta lannoitustasolla $330 \mathrm{~kg} \mathrm{~N}^{-1}$ hun se vanhassa aineistossa saavutettiin jo noin $260 \mathrm{~kg} \mathrm{~N} \mathrm{ha}^{-1} \mathrm{v}^{-1}$ lannoituksella. Parantuneen satovasteen taustalla ovat nurmilajikkeiden jalostuksen eteneminen, kasvukauden pidentyminen ja vastaava talven lyhentyminen sekä vähentyneet talvituhot. Mineraalilannoitteen typpi ohjautuu sadonmuodostukseen, mitä voidaan pitää sekä kasvintuotannon, lypsylehmien ruokinnan ja ympäristön kannalta edullisena ilmiönä. Typen satovastefunktion päivittäminen on välttämätöntä sekä nurmen tuotannon että ympäristövaikutusten realistisen arvioinnin kannalta.

Asiasanat: lannoitus, nurmenviljely, nurminata, ravinnetaseet, timotei, typpi 


\section{Johdanto}

Typpi (N) on kasviravitsemuksessa tärkein yksittäinen ravinne. Typellä on keskeinen rooli esimerkiksi aminohapoissa ja klorofyllissä sekä monissa aineenvaihduntatuotteissa ja nukleiinihapoissa. Typen puute ilmenee yleensä kasvien keltaisena värinä puutteellisen klorofyllisynteesin seurauksena. Lehdissä olevasta typestä noin puolet on sitoutuneena ribuloosi-1,5-bis-fosfaattikarboksylaasi- (Rubisco) entsyymeihin. Typellä on myös merkittävä rooli monien kasvihormonien osana tai niiden synteesissä.

Typpilannoituksen lisääminen nostaa kasvun lisäksi myös nurmisadon raakavalkuaispitoisuutta. Tämä ei ole yksiselitteisesti hyvä ilmiö, sillä lannoituksella aikaansaatu typen lisä kasvissa on hyödytöntä märehtijän ravitsemuksen kannalta sen jälkeen kun märehtijän minimitarve on tyydytetty (tyypillisesti 13-14\% raakavalkuaista nurmirehun kuiva-aineessa (Luke). Ylimääräinen typpi poistuu eläimestä virtsan mukana ja voi lisätä nurmiviljelyn ympäristökuormitusta. Koska typpi huuhtoutuu helpohkosti pohjaveteen ja saattaa aiheuttaa typpirajoitteisissa vesistöissä rehevöitymistä, typpilannoituksen käyttöä säädellään tarkasti sekä ympäristökorvausjärjestelmän että nitraattiasetuksen puitteissa (VnA 235/2015, VnA 931/2000). Yksi keskeinen ympäristöindikaattori on lannoituksen ravinnetase, joka lasketaan aina kokonaisravinteesta (tase $=$ annettu typpi - sadossa poistunut typpi; Turtola ym. 2017). Tase kuvaa ennen kaikkea viljelyn resurssitehokkuutta mutta myös typen huuhtoutumisriskiä (Turtola ym. 2017). Typpilannoituksen ylimäärä johtaa myös kasvuston nitraattipitoisuuden nousuun mikä on eläinten kannalta haitallista ja jopa vaarallista.

Typpilannoituksen satovastefunktion avulla voidaan arvioida mm. nurmen sadontuottoa, märehtijän ravitsemusta sekä viljelyn ympäristökuormitusta. Uusimmissa kotimaisissa nurmien typpilannoituksen yhteenvedoissa (Salo ym. 2013, Valkama ym. 2016) käytetyt satovastefunktiot perustuvat pääosin 1960-1970 luvulta peräisin oleviin aineistoihin, ja myöhempien aineistojen osuus on hyvin pieni. Julkaistujen funktioiden mukaan nurmen kuiva-ainesadon maksimi on noin 8.5 tn ha $^{-1} \mathrm{v}^{-1}$ ja se saavutetaan $325 \mathrm{~kg} \mathrm{ha}^{-1} \mathrm{v}^{-1}$ typpilannoituksella. Pääosin 1960-1970 lukujen kokeiden yhteenvedoissa päädyttiin suosittelemaan typpilannoituksen ylärajaksi $300 \mathrm{~kg} \mathrm{ha}^{-1} \mathrm{v}^{-1}$, koska suurempiin lannoituksiin liittyi selvästi kohonnut talvehtimisriski (Hiivola ym. 1974). Kun nurmen vuotuista typpilannoitusta myöhemmin EU:hun liityttäessä kiristettiin, kohdennettiin vähennys kolmannen lannoituksen määrään, jossa taustalla olivat sekä syksyllä käyttämättä jäävän typen huuhtoutumisriski että liian suuren tai liian myöhään annetun typen aiheuttama talvehtimisriski. Tämän hetkinen maksimilannoitus on 190-250 kg $h^{-1} \mathrm{v}^{-1}$ riippuen niittokerroista ja maan orgaanisen aineksen pitoisuudesta (VnA 235/2015, VnA 931/2000).

Viimeaikaisissa kokeissa sadot ovat olleet nykyisten typpirajoitustenkin puitteissa paljon nykyisen satofunktion ennustetta korkeampia (mm. Laine ym. 2017). Sama ilmiö nähdään myös maatilaaineistoissa, vaikka näissä keskimääräinen säilörehun satotaso onkin vain 5.5 tn ka ha ${ }^{-1}$ (Virkajärvi ym. 2015). Nämä havainnot antavat aiheen epäillä olemassa olevien satofunktioiden ajantasaisuutta. Näistä syistä Luonnonvarakeskuksen (Luke) ja Yaran yhteistyönä aloitettiin tutkimus, jossa tavoitteena oli selvittää typpilannoituksen vaikutus uusien nurmikasvilajikkeiden kasvuun, rehuarvoon ja ravinnetaseisiin, sekä verrata uusia tuloksia nykyisin käytössä oleviin satovastefunktioihin. Toinen tavoite oli saada tarkempaa tietoa typpilannoituksen vaikutuksesta nurmen rehuarvoon ja typen hyväksikäyttöön.

\section{Aineisto ja menetelmät}

Tutkimus toteutettiin Luken toimipaikoissa Maaningalla ja Ruukissa. Kokeet perustettiin kivennäismaille (Maaninka: karkea hieta, orgaaninen aines 2.7\%; Ruukki: hieno hieta, orgaaninen aines 5.4\%) vuonna 2014 ja käsittelyt toteutettiin vuosina 2015-2017. Kokeessa oli neljä toistoa ja koeruudut niitettiin kolmesti vuodessa. Pääruutuina olivat timoteilajikkeet Nuutti ja Grindstad sekä nurminata Valtteri. Osaruutuina olivat kahdeksan typpilannoitustasoa (0, 150, 200, 250, 300, 350, 400, $450 \mathrm{~kg}$ N $\left.\mathrm{ha}^{-1} \mathrm{v}^{-1}\right)$, joista kahden korkeimman tason oletettiin alentavan satoa erityisesti suurempien talvituhojen vaikutuksesta (Hiivola ym. 1974). Typpilannoitus jaettiin niittojen välillä (1., 2. ja 3. niitto) suhteessa $0.44-0.36-0.20$. Koeasetelmana oli epätäydellisten lohkojen osaruutukoe, jossa yhteen lohkoon kuului neljä saman lajikkeen typpilannoitustasoa. Koeruudut niitettiin kolmesti kesässä säilörehuasteella 
(D-arvotavoite 680-700 $\mathrm{g} \mathrm{kg}^{-1} \mathrm{ka}$ ) kukin lajike oman kasvurytminsä mukaisesti. Fosfori- ja kaliumlannoitus suureni typpilannoituksen myötä niin, ettei P- tai K-puutos rajoittaisi nurmen kasvua. Kokeessa määritettiin ka-sato, $\left(\mathrm{kg} \mathrm{ka} \mathrm{ha}^{-1}\right)$ ja talvituhot. Sadosta määritettiin sulavan orgaanisen aineen pitoisuus kuiva-aineessa (D-arvo; $\mathrm{g} \mathrm{kg}^{-1} \mathrm{ka}$ ) ja raakavalkuainen $\left(\mathrm{g} \mathrm{kg}^{-1} \mathrm{ka}\right.$ ) NIRS-menetelmällä (Valio Oy) jokaisesta niitosta. Kokonaissadon D-arvo ja raakavalkuainen laskettiin kuiva-ainesadoilla painotettuina keskiarvoina. Rehun nitraattityppipitoisuus $\left(\mathrm{g} \mathrm{kg}^{-1} \mathrm{ka}\right)$ määritettiin viideltä typpilannoitustasolta (0, 150, 250, 350 ja 450; Yara Oy, Pocklington, Iso-Britannia).

Tilastolliset analyysit tehtiin SAS 9.4-ohjelmiston Mixed-proseduurilla mallilla, jossa lajike, typpilannoitustaso, vuosi ja kaikki näiden yhdysvaikutukset olivat kiinteitä muuttujia. Satunnaisia muuttujia olivat kerranne ja lohko $\times$ kerranne, vuosi $\times$ kerranne ja vuosi $\times$ lohko $\times$ kerranneyhdysvaikutukset. Mallissa käytettiin Kenward-Rogerin vapausasteiden korjausta. Koepaikat ja niitot analysoitiin erikseen ja parivertailut tehtiin Tukeyn testillä.

\section{Tulokset}

Typpilannoituksen taso vaikutti voimakkaasti kaikkiin mitattuihin muuttujiin, mutta vaikutukset riippuivat myös lajikkeesta, vuodesta ja lajike×vuosi -yhdysvaikutuksesta (Taulukko 1). Lisäksi vaikutukset erosivat hieman niittojen välillä. Tässä keskitytään paikkakunta- ja lajikekohtaisiin vuosikeskiarvoihin yli koejakson.

Typpi nosti selvästi satoa ja suurimmat sadot saatiin lannoitustasoilla $350-450 \mathrm{~kg} \mathrm{~N} \mathrm{ha}^{-1} \mathrm{v}^{-1}$ kummallakin paikkakunnalla (Taulukko 1). Kummallakin koepaikalla typen vaikutuksen suuruus riippui koevuodesta ja lajikkeesta. Suurin kolmen vuoden keskiarvosato saatiin Ruukissa, jossa Nuutti tuotti 14.4 tn $\mathrm{ka} \mathrm{ha}^{-1} \mathrm{v}^{-1}$. Ensimmäisen kahden vuoden aikana korkeimmilla typpilannoituksilla saatiin satoa lajikkeesta riippuen 13-15 tn $\mathrm{ka} \mathrm{ha}^{-1}$. Kolmannen vuoden sato oli selvästi heikompi Maaningalla (maksimi 9.8 tn ka ha ${ }^{-1} \mathrm{v}^{-1}$ lannoituksella $350 \mathrm{~kg} \mathrm{~N} \mathrm{ha}^{-1} \mathrm{v}^{-1}$ ) kuin Ruukissa (maksimi 12.0 tn ka ha-1 $\mathrm{v}^{-1}$ lannoituksella $450 \mathrm{~kg} \mathrm{~N} \mathrm{ha}^{-1} \mathrm{v}^{-1}$ ). Maaningalla Valtterin sato oli korkeilla typpilannoituksilla pienempi kuin timoteilajikkeiden, kun taas Ruukissa Valtterin maksimisato oli parempi kuin Grindstadin. Ilman typpilannoitusta viljellyt ruudut tuottivat Ruukissa noin kaksinkertaisen sadon verrattuna Maaningalla saatuun satoon.

Typpilannoituksen nosto alensi kokonaissadon painotettua rehun D-arvoa, mutta eri tavoin eri vuosina ja eri lajikkeilla. Maaningalla lannoitusportaiden väliset erot eivät olleet merkityksellisiä välillä 300350 kg N ha ${ }^{-1} \mathrm{v}^{-1}$ ja Ruukissa vastaavasti välillä 200-450 kg N ha-1 $\mathrm{v}^{-1}$. Valtterin D-arvo laski vähiten typpilannoituksen seurauksena ja vastaavasti Grindstadin eniten. Typpilannoitus nosti sadon raakavalkuaispitoisuutta ja nousu riippui lajikkeesta ja vuodesta kummallakin paikkakunnalla.

Sadon nitraattityppipitoisuus $\left(\mathrm{NO}_{3}-\mathrm{N}\right)$ oli molemmilla timoteilajikkeilla yleisesti alhaisempi kuin

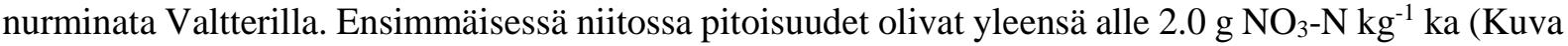
1). Toisessa ja kolmannessa niitossa nitraattityppipitoisuudet nousivat typpilannoituksen myötä mutta yli 2.0 arvoja esiintyi timoteillä vasta ylimmällä lannoitustasolla $\left(450 \mathrm{~kg} \mathrm{~N} \mathrm{ha}^{-1} \mathrm{v}^{-1}\right)$ ja Valtterilla kahdella korkeimmalla mitatulla lannoitustasolla (350 ja $450 \mathrm{~kg} \mathrm{~N} \mathrm{ha}^{-1} \mathrm{v}^{-1}$ ). Niittojen ero korostuu, kun tarkastellaan tuloksia niittokohtaisten lannoitusten kautta. Ensimmäisessä niitossa Valtterin korkein havaittu nitraattityppipitoisuus oli $2.9 \mathrm{~g} \mathrm{NO}_{3}-\mathrm{N} \mathrm{kg}^{-1} \mathrm{ka}^{-1 a n n o i t u s t a s o l l a ~} 198 \mathrm{~kg} \mathrm{~N}^{-1} \mathrm{Na}^{-1}$ nitto $^{-1}$, toisessa niitossa 3.8 g NO$_{3}-\mathrm{N} \mathrm{kg}^{-1}$ lannoitustasolla $162 \mathrm{~kg} \mathrm{~N}$ ha $^{-1}$ niitto $^{-1}$ ja kolmannessa niitossa $4.0 \mathrm{~g} \mathrm{NO}_{3}-\mathrm{N} \mathrm{kg}^{-}$

${ }^{1}$ ka lannoitustasolla $90 \mathrm{~kg} \mathrm{~N} \mathrm{ha}^{-1}$ niitto. 
Taulukko 1. Typpilannoituksen vaikutus kesän kokonaiskuiva-ainesatoon (Ka-sato), sulavuuteen (D-arvo), raakavalkuaispitoisuuteen (rv) ja N-taseeseen. Arvot ovat kolmen vuoden keskiarvoja.

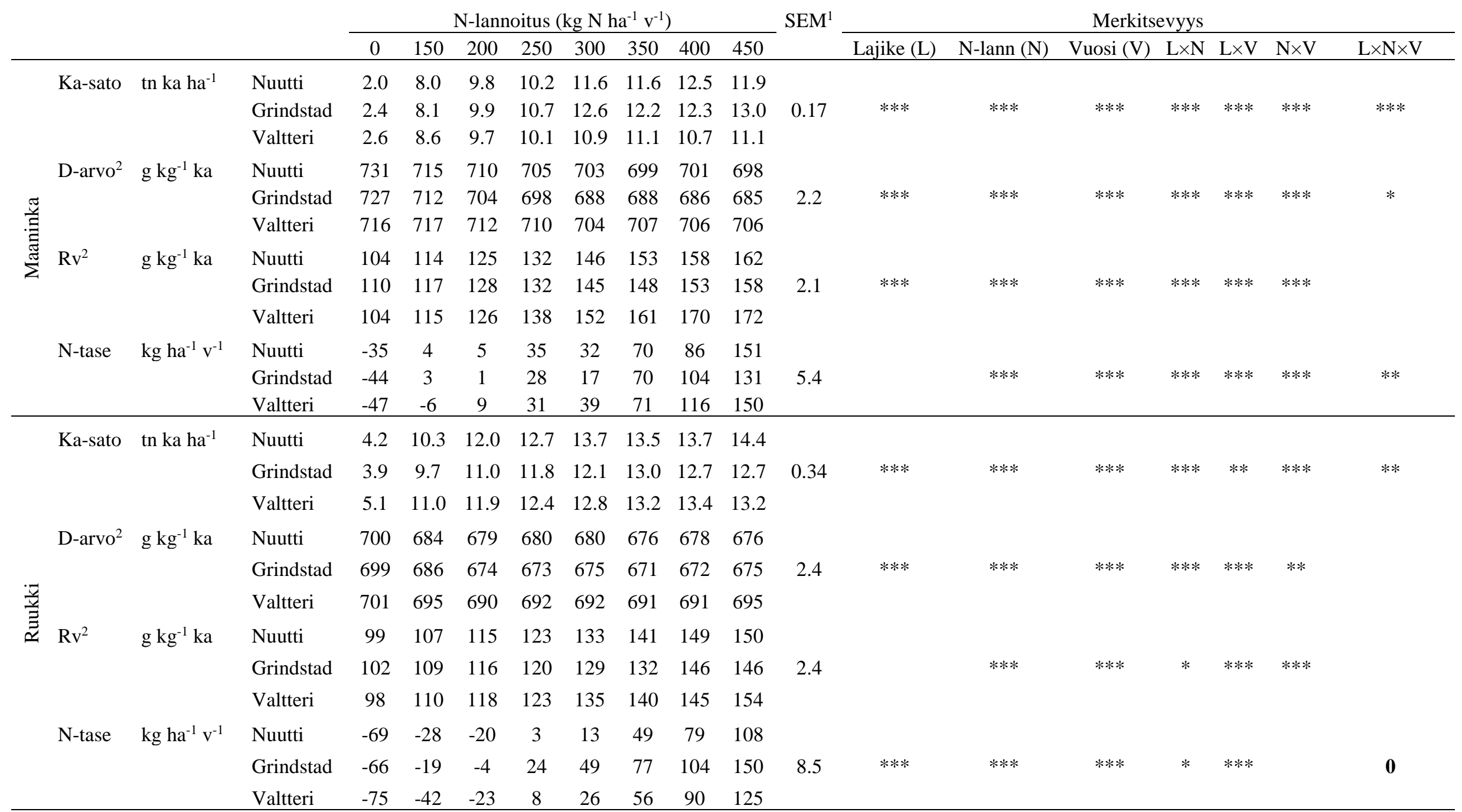

${ }^{1} \mathrm{SEM}=$ keskiarvon keskivirhe; ${ }^{2}$ Laskettu kuiva-ainesadoilla painotettuina keskiarvoina; *** $\mathrm{P}<0.001, * * \mathrm{P}<0.01, * \mathrm{P}<0.05,0 \mathrm{P}<0.10$ 


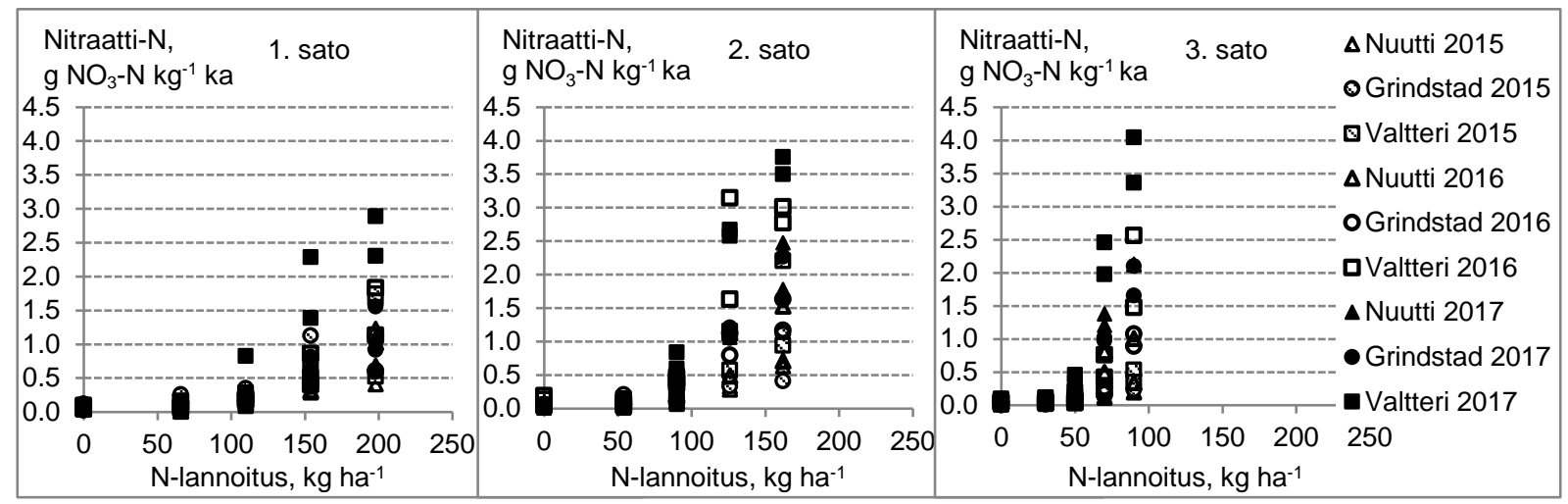

Kuva 1. Niittokohtaisen typpilannoituksen vaikutus kasvuston nitraattityppi $\left(\mathrm{NO}_{3}-\mathrm{N}\right)$-pitoisuuteen niitoittain ja lajikkeittain 2015-2017 (Maaninka ja Ruukki)

Viljelyn typpitase oli alle $200 \mathrm{~kg} \mathrm{~N} \mathrm{ha}^{1} \mathrm{v}^{-1}$ lannoituksella negatiivinen tai lähellä nollatasetta. Erityisesti Ruukissa ilman typpilannoitusta viljeltyjen ruutujen typpitase oli keskimäärin lähes $30 \mathrm{~kg} \mathrm{~N} \mathrm{ha}^{-1}$ (66\%) negatiivisempi kuin Maaningalla.

Talvituhot olivat pienet (alle 10\%) ensimmäisenä talvena molemmilla koepaikoilla. Myös toisena talvena Maaningalla talvituhot olivat alle 10\%, kun typpilannoitus oli välillä $0-300 \mathrm{~kg} \mathrm{~N} \mathrm{ha}^{-1} \mathrm{v}^{-1}$. Tätä suuremmat lannoitusmäärät lisäsivät selvästi talvituhoja, eniten Valtterilla (maksimi 28\%) ja vähiten Grindstadilla (maksimi 12\%). Ruukissa talvituhot olivat toisena talvena alle 10\%, kun typpilannoitus oli välillä 0-250 kg N ha ${ }^{-1} \mathrm{v}^{-1}$. Tätä korkeampi lannoitus lisäsi talvituhoja tasaisesti kaikilla lajikkeilla. Suurimmat talvituhot olivat välillä 13-29\% kun käytettiin lannoitustasoja 300-450 kg N ha-1 $\mathrm{v}^{-1}$.

\section{Tulosten tarkastelu}

Kolmen koevuoden perusteella (molemmat koepaikat, kaikki lajikkeet) $325 \mathrm{~kg} \mathrm{~N} \mathrm{ha}^{-1} \mathrm{v}^{-1}$ lannoituksella nurmi tuotti 12.4 tn $\mathrm{ka} \mathrm{ha}^{-1} \mathrm{v}^{-1}$ eli satovaste oli $43 \%$ suurempi kuin vanhassa aineistossa (Kuva 2a). Funktion mukainen satomaksimi oli aiempaa korkeampi eli 14 tn $\mathrm{ka} \mathrm{ha}^{-1} \mathrm{v}^{-1}$, joka saavutettiin $420 \mathrm{~kg} \mathrm{~N}$ ha $^{-1}$ vuosilannoituksella. Koska nurmirehuilla ei ole markkinahintaa, lannoituksen taloudellisen optimin määrittäminen ei ole yksiselitteistä, mutta se on luonnollisesti biologista optimia matalampi. Optimoinnissa on kyse tilan eläinten tarvitseman nurmirehun tuottamisesta mahdollisimman edullisesti.

Nurmen raakavalkuaispitoisuus nousi typpilannoituksen kasvaessa uudessa aineistossa hitaammin kuin aikaisemmissa kokeissa (Kuva 2b). Sinänsä sadon raakavalkuaispitoisuus oli matalahko (vrt. Rehutaulukot ja ruokintasuositukset 2015) ja korkeimmillaankin vain $172 \mathrm{~g} \mathrm{~kg}^{-1}$ ka vasta lannoitustasoilla $250 \mathrm{~kg} \mathrm{~N}$ ha $^{-1} \mathrm{v}^{-1}$ (Maaninka) ja $300 \mathrm{~kg} \mathrm{~N}$ ha $^{-1}$ vuosi $^{-1}$ (Ruukki). Matala raakavalkuaispitoisuus on tyypillinen kokeissa, joissa ei käytetä karjanlantaa. Korkeat nitraattityppipitoisuudet rehussa ( $>2 \mathrm{~g} \mathrm{~kg}^{-1} \mathrm{ka}$; Mayland ym. 2007) ovat haitallisia märehtijöille, mutta esitetyt raja-arvot vaihtelevat suuresti, etenkin koska nitraatin haitallisuuteen vaikuttavat ruokinnan kokonaisuus ja nitraattipitoisuuden äkilliset muutokset (Mayland ym. 2007). Valtterin nitraattityppipitoisuus nousi herkemmin kuin Nuutin ja Grindstadin. Tämän taustalla saattaa olla se, että typpilannoitus edisti timotein korren kasvua erityisesti jälkisadoissa. Tämä alentaa kasvuston kokonaistyppi- ja nitraattityppipitoisuutta, sillä suurin osa typestä on lehdissä (Virkajärvi ym. 2012). 


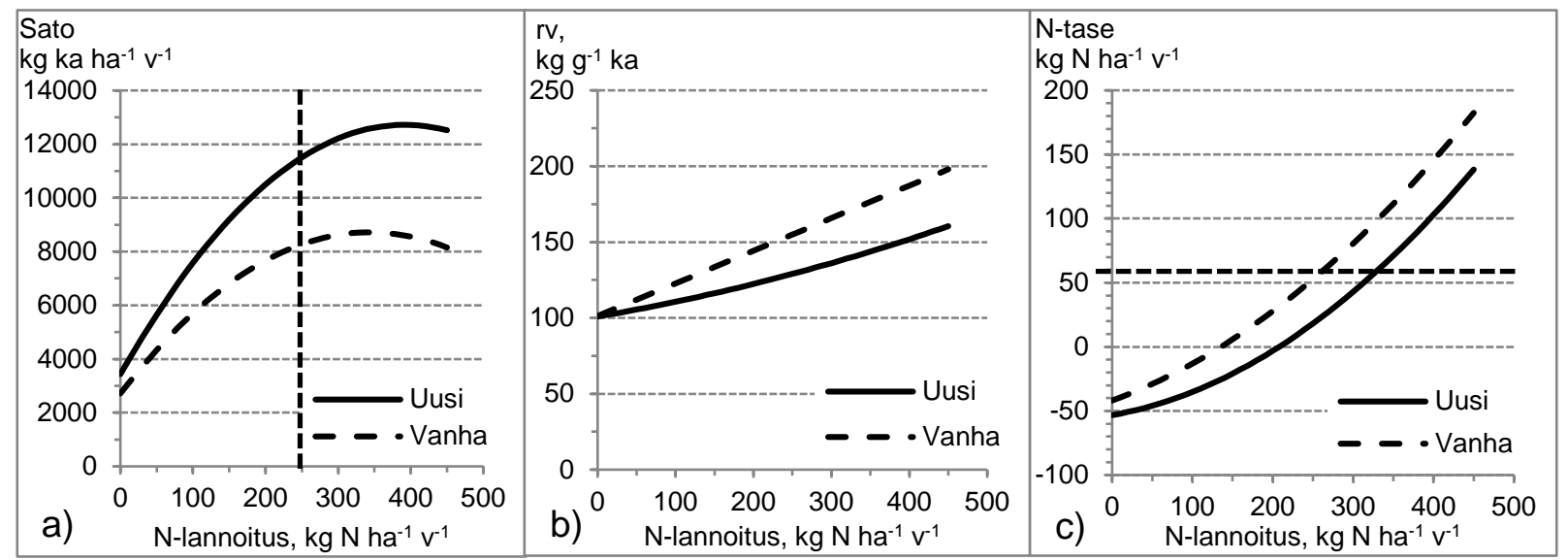

Kuva 2. Vanhojen ja uusien typpilannoituksen vastefunktioiden vertailu a) Kokonaiskuiva-ainesato, b) kokonaissadon raakavalkuaispitoisuus (rv) ja c) viljelyn vuotuinen typpitase. Uudet käyrät pohjautuvat kahden paikkakunnan, kolmen koevuoden ja kolmen lajikkeen muodostamaan aineistoon. Vanhat käyrät Salo ym. 2013 (a ja c) ja Virkajärvi 2016, julkaisematon (b). Nykyinen N-lannoitusmaksimi (250 kg N ha ${ }^{-1} \mathrm{v}^{-1}$; nitraattiasetus) ja suositeltu N-taseen maksimiraja (+60 kg N ha-1 $\mathrm{v}^{-1}$; Salo ym. 2013) on merkitty katkoviivoilla kuviin. Uusien funktioiden yhtälöt: Sato $=3436.4+47.401 \times \mathrm{N}$-lannoitus $-0.0605 \times \mathrm{N}$-lannoitus ${ }^{2}, \mathrm{Rv}=100.91+0.0874 \times \mathrm{N}$ lannoitus $+0.0001 \times \mathrm{N}$-lannoitus ${ }^{2}$, N-tase $=-53.262+0.1106 \times \mathrm{N}$-lannoitus $+0.0007 \times \mathrm{N}$-lannoitus ${ }^{2}$

Korkean sadontuoton seurauksena typen hyväksikäyttö oli selvästi parempi kuin aiemmissa kokeissa. Typen huuhtoutumisen kannalta hyväksyttävänä typpitaseena pidetään +60 kg N ha-1 (Salo ym. 2013). Vanhassa aineistossa kyseinen raja saavutettiin jo noin $260 \mathrm{~kg} \mathrm{~N} \mathrm{ha}^{-1} \mathrm{v}^{-1}$ lannoituksella (Kuva 2c). Nykyisessä kokeessa nurmelle voitiin antaa $300-350 \mathrm{~kg} \mathrm{~N} \mathrm{ha}^{-1}$ vuosi $^{-1}$ ennen kuin raja ylitettiin. Nurmien osalta voidaan myös ajatella, että hyväksyttävä taseen raja olisi yksivuotisia kasveja korkeampi, sillä sadossa poistumaton typpi on nurmivuosina sitoutunut maapäälliseen kasvustoon ja juuristoon (Turtola ym. 2017), eikä ole siis vastaavasti kokonaisuudessaan alttiina huuhtoutumiselle yksittäisenä vuotena, paitsi nurmen uusimisvuonna. Maaningan ja Ruukin välinen ero typpitaseessa ilman typpilannoitusta jääneillä koejäsenillä kuvaa maasta vapautuvan typen suurempaa vaikutusta Ruukissa (vrt. Salo ym. 2013, Valkama ym. 2016).

Parantuneen satovasteen taustalla ovat nurmilajikkeiden jalostushyöty, jonka arvioidaan olevan $0.5 \%$ vuodessa (Pärssinen 2016) ja kasvuolosuhteiden muuttuminen. Kasvukaudet ovat pidentyneet merkittävästi ja esimerkiksi timotein virallisten lajikekokeiden ensimmäinen niittopäivä on aikaistunut keskimäärin noin viikolla vuosien 1978 ja 2016 välisenä aikana, mikä mahdollistaa kolmannen niiton. Myös kasvukausien keskilämpötilan nousu (Tietäväinen ym. 2010) hyödyttää nurmikasveja pohjoisessa ilmastossa (Hakala ja Mela 1996, Höglind ym. 2013). Kasvukauden pidentymisen edullinen vaikutus liittyy myös talven lyhentymiseen. Talvituhojen merkitys on yleisesti vähentynyt ja esimerkiksi virallisten lajikekokeiden timotein ja nurminadan mittarilajikkeiden talvituhot olivat vuosina 19831990 7-16\% (Mustonen ym. 1991) ja vuosina 2009-2016 3.3-3.5\% (Laine ym. 2017). Lisäksi pidentynyt kasvukausi antaa nurmelle paremmat mahdollisuudet kompensoida mahdollisia talvituhoja.

Huomionarvoista on, että mineraalilannoitteen typpi ohjautui sadonmuodostukseen, mitä voidaan pitää sekä kasvintuotannon, lypsylehmien ruokinnan että ympäristön kannalta edullisena ilmiönä. Saatujen tulosten perusteella nurmen typpilannoitusta mineraalilannoitteena voisi nostaa kivennäismailla nykyisestä tasosta tasolle 300-350 $\mathrm{kg} \mathrm{ha}^{-1} \mathrm{v}^{-1}$ ilman että nurmen talvehtiminen, rehun laatu tai typpitase heikkenevät oleellisesti. Taloudellinen optimointi vaatii kuitenkin oman tarkastelunsa, jossa otetaan huomioon tilan eläinmäärä, käytettävissä oleva peltoala ja karjanlanta. Typen satovastefunktion päivittäminen on välttämätöntä sekä nurmen tuotannon tehostamisen että ympäristövaikutusten realistisen arvioinnin kannalta, etenkin, koska peltoalasta lähes kolmannes on nurmiviljelyssä. 


\section{Johtopäätökset}

Uusien tulosten perusteella nurmien typpilannoitusvaste on huomattavasti korkeampi kuin aikaisemmissa kokeissa. Typpi ohjautuu nimenomaan sadonmuodostukseen ja sen vaikutus raakavalkuaispitoisuuden nousuun on vähäisempi kuin aikaisemmissa kokeissa. Näiden seurauksena nurmen typpitase on alhaisempi kuin aikaisemmissa kokeissa. Typen käytön optimi kivennäismailla näyttää olevan selvästi korkeampi kuin aikaisempien aineistojen perusteella. Tämän tutkimuksen tulokset ovat myös osoitus siitä, että tutkimustietoa on päivitettävä aika-ajoin uusilla kokeellisilla tutkimuksilla muuttuvan tuotantoympäristön seurauksena. Saaduilla tutkimustuloksilla on merkittävä vaikutus arvioitaessa nurmien typpilannoituksen taloudellista optimia ja typpilannoituksen ympäristövaikutuksia. Nurmet kattavat yli kolmanneksen Suomen viljellystä peltopinta-alasta, joten niiden typpilannoituksen ympäristövaikutusten realistinen tarkastelu on välttämätöntä myös maatalouden kokonaiskuormituksen arvioinnin kannalta.

\section{Kirjallisuus}

Hakala, K., \& Mela, T. 1996. The effects of prolonged exposure to elevated temperatures and elevated CO2 levels on the growth, yield and dry matter partitioning of field-sown meadow fescue. Agricultural and Food Science in Finland 5: 285-298.

Hiivola, S.-R., Huokuna, E., \& Rinne, S.-L. 1974. The effect of heavy nitrogen fertilization on the quantity and quality of yields of meadow fescue and cocksfoot. Annales Agriculturae Fenniae 13: 149-160.

Höglind, M., Thorsen, S. M., \& Semenov, M. 2013. Assessing uncertainties in impact of climate change on grass production in Northern Europe using ensembles of global climate models. Agricultural and Forest Meteorology 170: 103-113.

Laine, A., Högnäsbacka, M., Niskanen, M., Ohralahti, K., Jauhiainen, L., Kaseva, J. \& Nikander, H. 2017. Virallisten lajikekokeiden tulokset 2009-2016. Luonnonvara- ja biotalouden tutkimus 1/2017. Luonnonvarakeskus. $270 \mathrm{~s}$.

Luonnonvarakeskus 2015. Rehutaulukot ja ruokintasuositukset. Märehtijät - Siat - Siipikarja - Hevoset. Luonnonvara- ja biotalouden tutkimus 40/2015. Luonnonvarakeskus. $80 \mathrm{~s}$.

Mayland H.F., Cheeke, P.R., Majak, W. \& Goff, J. P. 2007. Forage induced animal disorders. Teoksessa: Barnes, R.F., Nelson, C.J., Moore, K.J. \& Collins, M. (toim.). Forages: The science of grassland agriculture. 6th ed. Oxford, UK: Blackwell Publishing. s. 687-708.

Mustonen, L., Rantanen, O., Niemeläinen, O., Pahkala, K: \& Kontturi, M. 1991. Virallisten lajikekokeiden tuloksia 1983-1990. Maatalouden tutkimuskeskus, Tiedote 2/91. $147 \mathrm{~s}$.

Pärssinen, P. 2016. henk. koht. tiedonanto 2.2.2016

Salo, T., Turtola, E., Virkajärvi, P., Saarijärvi, K., Kuisma, P., Tuomisto, J., Muurinen, S. \& Turakainen, M. 2013. Nitrogen fertilizer rates, $\mathrm{N}$ balances and related risk of $\mathrm{N}$ leaching in Finnish agriculture. MTT report 102. Maa- ja elintarviketalouden tutkimuskeskus. $37 \mathrm{~s}$.

Tietäväinen, H., Tuomenvirta, H., \& Venäläinen, A. 2010. Annual and seasonal mean temperatures in Finland during the last 160 years based on gridded temperature data. International Journal of Climatology 30: 2247-2256. Turtola, E., Salo, T., Miettinen, A., Iho, A., Valkama, E., Rankinen, K., Virkajärvi, p., Tuomisto, J., Sipilä, A., Muurinen, S., Turakainen, M., Lemola, R., Jauhiainen, L., Uusitalo, R., Grönroos, J., Myllys, M., Heikkinen, J., Merilaita, S., Cano Bernal, J., Savela, P., Kartio, M., Salopelto, J., Finér, A. \&

Jaakkola, M. 2017. Hyötyä taseista. Ravinnetaseiden tulkinta ympäristön ja viljelyn hyödyksi. Luonnonvara- ja biotalouden tutkimus 15/2017. Luonnonvarakeskus. $70 \mathrm{~s}$.

Valkama, E., Rankinen, K., Virkajärvi, P., Salo, T., Kapuinen, P. \& Turtola, E. 2016. Nitrogen fertilization of grass leys: yield production and risk of $\mathrm{N}$ leaching. Agriculture, Ecosystems and Environment 230: 341-352.

Virkajärvi, P., Pakarinen, K., Hyrkäs, M., Lemettinen, J-P., Rinne, M., Manninen, O. \& Seppänen, M. 2012. Nurmen kasvu- ja kehitysprosessit. NURFYS-hankkeen 2006-2011 loppuraportti. Maa- ja elintarviketalouden tutkimuskeskus. MTT raportti 56. $120 \mathrm{~s}$.

Virkajärvi, P., Rinne, M., Mononen, J., Niskanen, O., Järvenranta, K. \& Sairanen, A. 2015. Dairy production systems in Finland. Teoksessa: van den Pol-van Dasselaar, A., Aarts, H.F.M., De Vliegher, A., Elgersma, A., Reheul, D., Rei-jneveld, J.A., Verloop, J. \& Hopkins, A. (toim.). Grassland and forages in high output dairy farming systems. Proceedings of the 18th symposium of the European Grassland Federation, in June in Wageningen, the Netherlands. Grassland Science in Europe 20: 51-66. 